\title{
The "Rose” Revolution: Did It Bring Change to Kyrgyzstan?
}

\author{
Susanna Ayvaz \\ Suleyman Sah University, Istanbul, Turkey \\ Nergis Aziz \\ State University of New York, New York, USA \\ Suleyman Sah University, Istanbul, Turkey \\ Kenneth L. Shaw \\ State University of New York, New York, USA
}

\begin{abstract}
Twenty years have passed since the collapse of the USSR. Newly independent states have been faced with numerous problems that have affected their social, economic and political spheres. Some of these countries have overcome troubled times, some have not. The Kyrgyz Republic is one of the countries still struggling to resolve economic problems and ensure political stability. Recent political turmoil has led to even worse conditions in the country. Changes in governance have not brought adequate reforms to this country. This study attempts to identify socio-economic and political conditions in Kyrgyzstan after more than a year has passed since the "Rose" revolution in 2010. In particular, this paper examines the import and export markets of the country as well as the manufacturing and banking industries to develop insights into how the country may address its various problems. The authors have employed data from the country as well as personal insights to conclude that the future prospects for Kyrgyz Republic depend heavily on its ability to harmonize the political culture of the republic.
\end{abstract}

Keywords: Kyrgyzstan transition economy, "Rose” revolution, colourful revolutions, post-independence economy, Kurmanbek Bakiev, structure of Kyrgyzstan’s economy

\section{Introduction}

Countless articles and news releases start with the sentence "After the collapse of the USSR..." that it has become a cliché. Twenty years have passed since the collapse of the USSR. This period of time seems to be sufficient for the economic development of new independent states and for the transition to "market" economy, but in reality, it did not happen. In reality, after the collapse of the USSR some independent states went through “colorful” revolutions: Georgia (2003), Ukraine (2004), Kyrgyzstan (2005), Belarus (2006), Armenia (2008), Moldova (2009), and again, Kyrgyzstan (2010).

The Kyrgyz Republic declared its independence on August 31, 1991. The country joined the Commonwealth of Independent States in 1991, and elected its first president Askar Akaev (Kyrgyzstan Country Review, 2011). It was internationally recognized as a sovereign state. Kyrgyzstan was the most promising

Susanna Ayvaz, Ph.D., Department of Economics, Suleyman Sah University.

Nergis Aziz, Ph.D., Marketing and Management Department, State University of New York and Suleyman Sah University.

Kenneth L. Shaw, Ph.D., Marketing and Management Department, State University of New York.

Corresponding concerning this article should be addressed to Susanna Ayvaz, Department of Economics, Suleyman Sah University, Hayriye Dumankaya Yerleskesi, Atalar Mah., Sehit Hakan Kurban Street, No. 44, Kartal-Istanbul 34865, Turkey. E-mail: sayvaz@ssu.edu.tr. 
country among other independent Central Asian countries. This country compared to its neighbors customized general elections, adopted a democratic form of government, it did not prevent opposing political parties from performing political activities and tried to provide freedom of the press.

Kyrgyzstan embraced the "Silk Road Diplomacy" (an official document dated 17 September 1998 and adopted by the United Nations) doctrine in order to obtain its position in the international arena (Askar Akaev, 1999). According to the ex-president Akaev, owner of the idea, implementation of the doctrine would have resulted in stability and security in the Central Asia region and Kyrgyzstan would have developed according to the "Swiss model". Therefore, Kyrgyzstan at that time was defined as an "island of democracy" or as the "Switzerland of Central Asia". Today, the country can be named as an island of revolutions. Just five years passed between two revolutions that took place in 2005 and 2010. Mr. Akaev fled from the country as the "Tulip Revolution” took place in 2005. Ex-president Akaev is a professor in physics at the Moscow State University (Moscow, Russia) at the present time.

In 2005, the “Tulip Revolution” Bakiev-lead opposition promised to bring a parliamentary system while overthrowing ex-president Akaev. Kyrgyzstan's parliament tried to change the Constitution that was ensuring a parliamentary system several times, but it failed to pass. Thus, the Kyrgyz administration spent a long time on the power struggle and it was not interested in increasing standards of life and developing the economy. Therefore, people struggled with poverty. Privatization of state property led to enormously increasing prices. The Kyrgyz people had become dissatisfied with the living standards. In addition, the Kyrgyz Republic had the problem of corruption in all government departments. Bakiev and his government failed to establish authority that resulted in increases in crime and violence, affecting production levels (Challenges Beyond Politics, 2006). The Kyrgyz people accused Bakiev's government of setting up a dictatorship and protecting the interests of his family.

One of the main reasons for the outbreak of the crisis in 2010 in Kyrgyzstan and perhaps the most important one was the uncertain political situation in the country. Ex-president Bakiev was overthrown in April 2010. Then, the temporary president of Kyrgyzstan formed an interim government headed by Roza Otunbayeva. The country held a referendum on the constitution on 27 June 2010 and parliamentary elections took place on 10 October 2010. The new government was formed in December 2010.

The current three-party coalition tries to work closely together on political and economic reforms. Political stability is not yet ensured in the country therefore most investors utilise a "wait-and-see policy" towards coming back to this country (Macroeconomic Outlook, 2011).

\section{Socio-economic and Political Conditions in Kyrgyzstan After the Revolution in 2010 Socio-economic Conditions}

Kyrgyzstan's economy is based on general sectors such as agriculture, livestock, industry, gold mining and tourism. However, all these sectors are underdeveloped. For example, in agriculture, available lands are not used efficiently. In addition, $80 \%$ of land is the mountainous area of the country. But the forestry is not developed. Underdevelopment of these sectors led to the country's dependence on imports. The remaining application from the period of Soviet Union central planning is the utilization of rich water resources in order to generate electricity. Therefore, electric energy as an item of export holds a relatively high share. However, the old technologies are still used in the production of electrical energy and it reduces the efficiency. Because relations between countries broke due to the dissolution of the Soviet Union, the sectoral structure of the industry of the country has undergone negative changes. In recent years, industrial engineering, light industry 
and manufacturing sectors experienced a sharp decline in the share of total Gross Domestic Product. Tourism is at the new development stage.

When it comes to gold mining, in the next few years, gold production is expected to decline in the economy and this can lead to undesirable results.

Kyrgyzstan was a raw material supplier in the USSR and was sending these sources to other parts of the USSR for processing. The ownership of production factors belonged to the state and economic activities were planned by a central authority during the Soviet era. Central planning was planning production units and prices. Kyrgyzstan was not able to export and import and conduct economic relations with other states until 1992. In the middle of the 1990s the government began actively negotiating trade agreements with other countries and companies to establish joint ventures in various fields. However, the transition to a market economy was very painful. In 1992 (in comparison with 1991) national income fell by 26\%, industrial production by 27\% and agriculture by 14\% (Ekonomika Kyrgyzstana, 2001). Among the reasons for this situation are inflation, migration of skilled personnel, high corruption, decline in key business sectors including industry, etc., and lack of resources. The growing economic crisis caused the country to drift and foreign loans was limited and ran out quickly. In order to provide necessary capital for the development of the country conditions for foreign investments, such as security, political stability and legal assurance, should be ensured. However, the required conditions were not provided in the country.

One of the most important features of Kyrgyzstan is keeping the family or clan interests over national interests. For example, during privatization in the era of independence large parts went to Akaev's and Bakiev's families and ministers or administrators. They had the mechanisms to justify their gains because politicians in Kyrgyzstan have the right to have their own business. Therefore, they can justify non-official revenues. This corruption-based system also includes the audit system. In sum, the country has fallen in employment and poverty has risen because of corruption and it cannot make progress and move forward.

Revolutions that took place in the country in 2005 and in 2010 made the situation even worse. Most of the social facilities were destroyed during the uprising, and inventories of the key enterprises were plundered. Commercial enterprises have gone bankrupt due to losses in their stocks. After a two-day "revolution” workers did not go to work for weeks because of fear. All this has created a very negative impact on the economy of Kyrgyzstan.

The overall state of Kyrgyzstan's economy is shown in Table 1.

Table 1

Main Macro-economic Indicators of Kyrgyz Republic (as \% of the Previous Year)

\begin{tabular}{lcccccccccccccccccc}
\hline Indicator & 1995 & 1996 & 1997 & 1998 & 1999 & 2000 & 2001 & 2002 & 2003 & 2004 & 2005 & 2006 & 2007 & 2008 & 2009 & 2010 \\
\hline Gross domestic product & 94.6 & 107.1 & 109.9 & 102.1 & 103.7 & 105.4 & 105.3 & 100.0 & 107.0 & 107.0 & 99.8 & 103.1 & 108.5 & 107.6 & 102.3 & 98.6 \\
Industrial production & 75 & 104 & 140 & 105 & 96 & 106 & 105 & 89 & 117 & 105 & 88 & $90^{\mathrm{a}}$ & 107 & 115 & 93.6 & 109.8 \\
Agricultural production & 98 & 115 & 112 & 103 & 108 & 103 & 107 & 103 & 103 & 104 & 96 & 102 & 102 & 100.8 & 107.4 & 97.2 \\
Capital investments & 182 & 119 & 96 & 64 & 122 & 137 & 86 & 90 & 93 & 102 & 106 & 155 & 105 & 106 & 119.7 & 90.2 \\
Freight carried & 70 & 108 & 94 & 99 & 115 & 105 & 97 & 105 & 109 & 104 & 91 & 99.8 & 116 & 121 & 106.8 & 101.1 \\
Retail trade turnover & 94.0 & 101.8 & 108.8 & 110.8 & 100.8 & 107.4 & 106.2 & 108.3 & 110.1 & 114.7 & 113.6 & 115.8 & 113.8 & 109.0 & 99.9 & 97.5 \\
Industrial producers price & 143 & 132 & 130 & 109 & 151 & 130 & 110 & 106 & 107 & 109 & 103 & 115 & 111.9 & 126 & 112.0 & 122.9 \\
index & 143 & 132 & 123 & 110 & 136 & 119 & 107 & 102 & 103 & 104 & 104 & 106 & 110 & 125 & 106.8 & 108.0 \\
Consumer price indices & 143
\end{tabular}


(Table 1 continued)

\begin{tabular}{|c|c|c|c|c|c|c|c|c|c|c|c|c|c|c|c|}
\hline Indice & 1995 & 1996 & 1997 & 1998 & 1999 & 2000 & 2001 & 2002 & 2003 & 2004 & 2005 & 2006 & 2007 & 2008 & 20092010 \\
\hline Export to $C$ & 121 & 146 & 81 & 72 & 79 & 113 & 81 & 100.1 & 119 & 137 & 110 & 125 & 150 & 104 & 67.25104 .7 \\
\hline countries & 119 & 80 & 254 & 99 & 96 & 110 & 104 & 103 & 120 & 117 & 83 & 113 & 137 & 152 & 108.9105 .6 \\
\hline Import fro & 169 & 138 & 90 & 101 & 59 & 115 & 86 & 126 & 127 & 142 & 117 & 146 & 154 & 144 & $\begin{array}{ll}78.63 & 99.7\end{array}$ \\
\hline $\begin{array}{ll}\text { Import } & \text { from } \\
\text { countries } & \end{array}$ & 157 & 208 & 78 & 147 & 85 & 75 & 82 & 126 & 116 & 117 & 117 & 172 & 123 & 149 & 70.09114 .3 \\
\hline
\end{tabular}

Note. ${ }^{\text {a }}$ Source: Interstate Statistical Committee of CIS. Retrieved July, 2011, from http://www.cisstat.com/rus/macro/kir.htm.

Analysis of significant trends of the Kyrgyz economy has shown that although there are satisfactory results at the macroeconomic level, balances at the structural level are not provided. Low pace of Gross Domestic Product growth in the country, large budget deficits, high rates of public debt and high credit interest rates, as well as an increase in public spending, high unemployment and unequal development of regions of the country are current issues of this country.

There are data on inflation and GDP below that provides an overview of effects of political turmoil on Kyrgyzstan's economy.

As shown in Figure 1, there is an increase in inflation and a rise in political turmoil that the country experienced in 2002, 2005, 2006, and 2010.

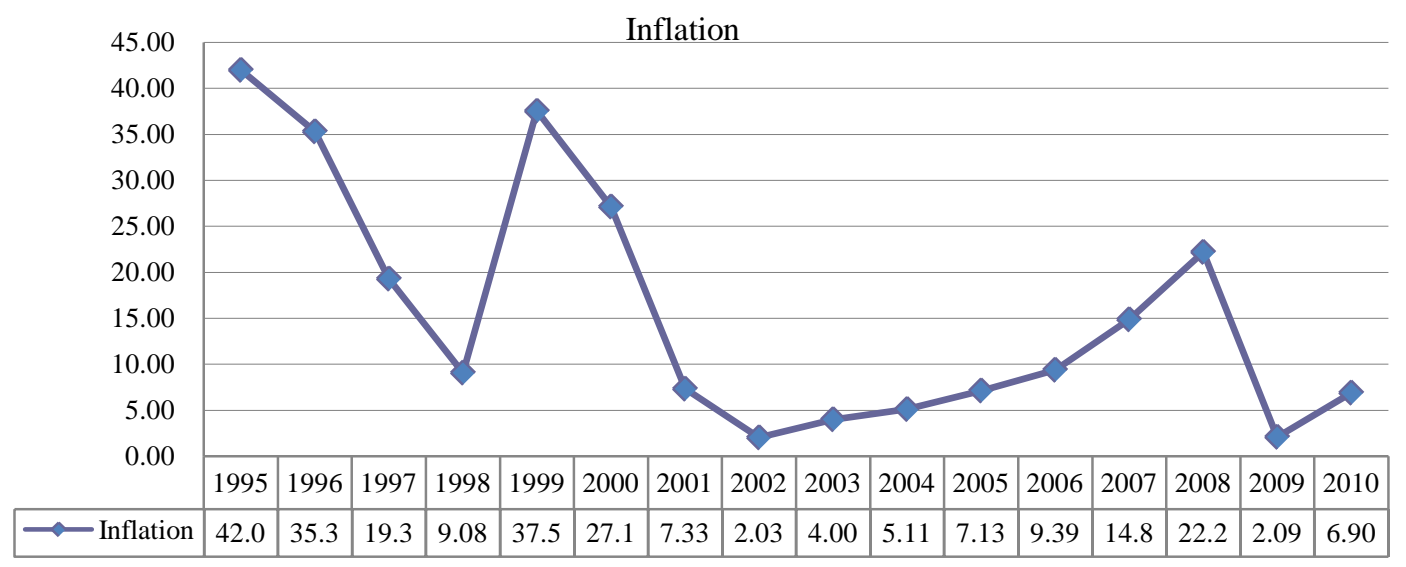

Figure 1. Inflation (GDP deflator (annual\%))—Kyrgyz Republic. Source: Data and Statistics for Kyrgyz Republic (2010); IMF Country Report No. 11/155, p. 101.

Decline in GDP after the events in Kyrgyzstan can be observed in Figure 2.

Reforms in recent years have caused a slight increase in GDP and investment, but the results lose significance due to increasing inflation. Increases in import prices are the main cause of inflation. Especially as import prices of items such as grain, fuel, food and metal items increase, inflation is getting negatively affected. Another factor is the increase in inflation associated with monetary policy implemented in the country. In addition, the rapid growth in government spending affects inflation negatively. The high rate of the dollar (USD \$) against the som (Kyrgyz money unit) leads to an uncompetitive situation for products manufactured in Kyrgyzstan compared with other countries' products. Inflation is being addressed with the wrong methods. The high rate of inflation indicates the ineffectiveness of policy implemented by the Central Bank of Kyrgyz Republic (only inflation-focused control policies are applied). Government provides loans to create conditions for productive investment rather than increase, the economy instead of ensuring conditions in order to increase 
investment in manufacturing.

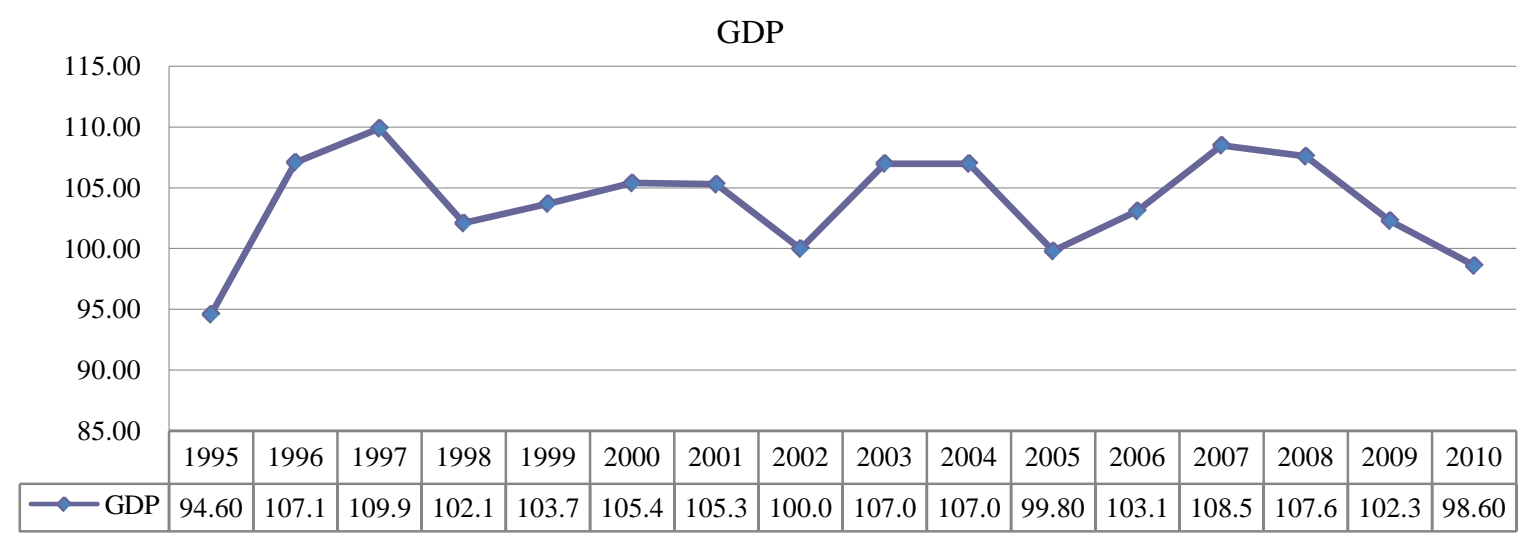

Figure 2. GDP-Kyrgyz Republic (as \% of the previous year). Source: Interstate Statistical Committee of CIS. Retrieved July, 2011, from http://www.cisstat.com/rus/macro/kir.htm.

The government has begun to work upon several projects to rebuild the economy. Projects mainly include plans to develop the agricultural sector, tourism and hydropower generation. However, political instability is still an important obstacle in realizing these reforms. Kyrgyzstan does not have prominent oil reserves and is dependent on neighboring countries to keep growth alive during this transition period. Therefore, Kyrgyzstan may be falling behind other economies in the region. The Asian Development Bank expects a 20\% drop in GDP growth in Kyrgyzstan over the next 10 years (Macroeconomic Outlook, 2011).

\section{Political Conditions}

According to the Constitution of the Kyrgyz Republic, the Kyrgyz Republic is a democratic state established according to sovereign, independent, legal and secular state guidelines (Article 1).

Kyrgyz Republic Government Forces, the President, Jogorku Kenes (Legislative Assembley and People’s Represenattive Assembley), Government is carried out by the Local Government Bodies and Courts of the Kyrgyz Republic (Article 7). Parliament (Jogorku Kenes) is the Kyrgyzstan's highest legislative body. The country's highest executive body is the government; the highest judicial body is the Constitutional Court. However, there was a monarchy in the country. For example, the President had power to appoint and remove judges including Constitutional Court judges too. Therefore, the independence of the judiciary was under question there.

After the "Tulip Revolution” Kurmanbek Bakiev came to power and promised reforms in order to overcome such drawbacks. However, he did not keep his promise. He assigned his sons, relatives and close friends to all important positions in order strengthen his own position, i.e., Adil Bakiev's (brother)—Economic Affairs and Investment Consultant of the Ambassador in China; Janis Bakiev (brother)-President of the State Security Committee; Marat Bakiev (brother)—Ambassador to Germany; Marat Bakiev (son)—Advisor to the President of the State Committee for National Security; Maksim Bakiev (son)—Chairman of the Board of Investment and Development). However, the Kyrgyz people began to reveal their discomfort when Kyrgyzstan's most important assets were shared among family members and their followers in the "privatization” process. According to the Kyrgyz political scientists, Bakiev's family was holding all the power in their hands and they were taking decisions ignoring the opinions of the public, foreign partners and 
opposition.

The Kyrgyz constitution can be considered as partly liberal. However, activities of the ex-president Bakiev who was head of the Executive Branch made it ineffective. More precisely, the constitution was used by those in power to establish an authoritarian order. Opposition was always under suppression. During ex-president Bakiev period the election laws were changed in favor of those in power (each party to collect at least $0.5 \%$ of votes in order to send their deputies) and during the elections in Jogorku Kenes representatives of opposition parties could not enter Parliament. There was no fair electoral system in the country. For example, ex-president Bakiev had the authority to determine electoral commission. Therefore, he was gaining elections by putting pressure on members of electoral commissioners.

Increased activity of the United States in Central Asia led to paying attention to Kyrgyzstan relations with the US. In fact, the US did not perceive Kyrgyzstan as a strategic partner for a long time because of the small size of this country. However, the USA was among the first countries to recognize the independence of Kyrgyzstan (December 27, 1991). The United States did not play an important role in regional policy of Kyrgyzstan in the first half of the 1990s. But since 2000, U.S. policy has become more active in Central Asia because of the operation in Afghanistan. Transit of U.S. military forces through Central Asia was both more comfortable and safer.

The presence of U.S. bases reinforces long-term existence of the United States in the region. Such bases can be useful in a case of conflict with Iran. At the same time the U.S. presence in the region reduces the effect of Russia and China. The main reason to place the air base in Kyrgyzstan was that the United States wanted to ensure the stability of the region. As a matter of fact, the Kyrgyz side also accepts that the U.S. operation in Afghanistan led to deterioration of the infrastructure of the Taliban and played an important role in the removal of the external threats over this country (Dundich, 2010).

U.S. and Russian governments may declare that neither of them is interested in the political crisis in Kyrgyzstan, but the situation reveals the contrary. The presence of U.S. and Russian military bases in the region is the best support of this fact. The Kyrgyz government was always trying to ensure a balance between the interests of Washington and Moscow, but both the U.S. and Russia are not satisfied with this statement. The United States and Russia's influence can be seen in two uprisings that took place in 2005 and 2010.

\section{Conclusion}

Kyrgyzstan gained independence 20 years ago and it was the first among the countries of Central Asia in its efforts to adopt democracy. Kyrgyzstan has been involved with numerous socio-economic problems since its independence but it continuously tried to transit to a market economy. Socio-economic problems affected transition to a liberal economic system in a very negative way. Moreover, these problems block investments and particularly foreign investments that are the main elements of a free economic system. Investments which are the fundamental basis of economic development are proportional to the political stability. However, today necessary resources are not available from the state budget, public or private sectors due to political and social instability that occurred after political crises in 2005 and 2010 in Kyrgyzstan. Therefore, foreign investment is a very important but controversial situation of Kyrgyz's "real sector" and creates problems for investors. Stability is one of the main assets that investors look for in order to invest in a particular country.

Kyrgyzstan had serious economic losses during the revolutions, but it seems that their more devastating losses may occur in the future. The Kyrgyz economy lost its attractiveness as a state for investments and 
collaboration for neighboring and world countries having witnessed the revolt of the uncontrolled forces in the country. However, this cooperation is very important for the country's prosperity because Kyrgyzstan does not have either gas, or the financial capital, or high technology in order to enter the world market. State-owned industries are agriculture, trade, energy, gold, uranium resources, and tourism in Issyk-Kul. Almost all of these vital sectors of Kyrgyzstan's economy depend on external factors. The country's resources could not be transformed into economic prosperity because of the shortage of capital and knowledge resources, mismanagement and inadequate legal regulation.

There were positive expectations related to ex-president Bakiev as he came to power after the 2005 "Tulip Revolution”. People were tired of economic problems and wanted change in their lives. However, Bakiev did not do anything in order to solve both the internal problems, i.e., the clan system, corruption, unemployment, the distinction between north and south, as well as regional issues, i.e., border issues, water issues, drug trafficking, terrorism, etc., in his 5-year presidential period. Moreover, a further deterioration of the country's economy in 2010 led to the second uprising. In April 2010 after the "Rose Revolution” (some resources name the revolution after the opposition party leader Roza Otunbayeva (roza means rose in Russian)) Roza Otunbayeva came to power and formed a government. But in the future in Kyrgyzstan in terms of political developments what may be very curious about these developments is the economic angle. Coups were attempted during the severe economic losses, but considering the future status of the Kyrgyz economy it seems more devastating losses that may occur.

Kyrgyzstan has a very important geopolitical position therefore it has strategic importance to the United States and the Russian Federation. Furthermore, there are many prerequisites that will play an important role in the economic future of Kyrgyzstan. Kyrgyzstan is the only country in the region that does not have any problem with a shortage of water resources. According to scientists depletion of water resources in neighboring countries such as Uzbekistan and Kazakhstan can take place within the next few years. In addition, the problem of drinking water for Central Asia is always very current.

Kyrgyzstan as a geographic area holds an importance in terms of global competition among the USA, Russia and China. China's access to Central Asia is possible only through this region. Also, Russia's and the U.S. military presence in the territory of Kyrgyzstan may lead to exacerbation of competition in various areas in the near future (Knyazev, 2011, p. 55).

The main goal of all conducted reforms was a transition to a market economy. However, institutional reforms have not been succeeded by copying developed countries' models. Reforms were aimed at privatization, liberalization and loose monetary policy. However, economic conditions steadily have worsened because of the country's low industrial level, the lack of products ready for export, resource conservation and poor management of the economy.

\section{References}

Akaev, A. A. (1999). The silk road diplomacy, doctrine of the president of Kyrgyzstan, Bishkek. Challenges Beyond Politics, Emerging Europe Monitor: Russia \& CIS, 10(3), 9, March 2006.

Business Monitor International, Kazakhstan and Central Asia Defence and Security Report Q3. (2011). Macroeconomic outlook 2011 (pp. 65-66). Kyrgyzstan.

Dundich, A. S. (2010). Kirgiziya Mezhdu “Velikimi”... Journal of International Relations Theory and World Politics, 8, 2(23), Retrieved June 30, 2011 from http://www.intertrends.ru/twenty-three/014.htm

Gusman, M. (2008). Formula Vlasti, Kurmanbek Bakiev, President of the Kyrgyz Republic (Interview), ITAR TASS (Russian 
News Agency). Retrieved June 23, 2011, from http://www.itar-tass.com/v1/169.html

History. (2011). Kyrgyzstan Country Review, 6-9. Retrieved January 2, 2011, from http://web.ebscohost.com.ezproxy.oswego.edu:2048/ehost/detail?vid=4\&hid=126\&sid=bdba1ede-d714-402e-b39c-7f5d3091 5d96\%40sessionmgr111\&bdata=JnNpdGU9ZWhvc3QtbGl2ZSZzY29wZT1zaXRl\#db=bah\&AN=58483758

International Monetary Fund. (2011). Kyrgyz Republic country report. Retrieved June, 2011, from http://www.imf.org/external/pubs/ft/scr/2011/cr11155.pdf

Interstate Statistical Committee of CIS. (2011). Main macroeconomic indicators of Kyrgyzstan. Retrieved July, 2011, from http://www.cisstat.com/rus/macro/kir.htm

Knyazev, A. A. (2011). The recent developments in Kyrgyzstan: Past, present and future. Center for Middle Eastern Strategic Studies, Report No. 26, Bishkek.

NEWSru.com (Russian online news site). (2009). Kyrgyz parliament approved with drawl U.S. air base of the country. Retrieved June 24, 2011, from http://www.newsru.com/world/19feb2009/parlament_manas.html

Vremya Vostoka (East Time). (2001). Kyrgyzstan's economy. Retrieved June, 2011, from http://www.easttime.ru/countries/topics/1/4/25.html

World Bank. (2010). Data and statistics: Kyrgyz Republic. Retrieved from http://web.worldbank.org/WBSITE/EXTERNAL/COUNTRIES/ECAEXT/KYRGYZEXTN/0,,menuPK:305786 pagePK:14 1132 piPK:141109 theSitePK:305761,00.html 